Brit. F. vener. Dis. (1970) 46, 18

\title{
Investigation of a specific IgM antibody test in neonatal congenital syphilis
}

\author{
M. SEPETJIAN, F. TISSOT GUERRAZ, J. C. MONIER, J. L. NIVELON, AND \\ J. THIVOLET \\ WITH THE ASSISTANCE OF N. SIMEON AND L. DAVID
}

Laboratoire d'Hygiène et d'Action Sanitaire et Sociale de la Faculté Mixte de Médecine et de Pharmacie, Université de Lyon, France

IN a recent study, Scotti and Logan (1968) have shown that it is possible to add to the classical criteria for diagnosis of congenital syphilis a technique, derived from the fluorescent treponemal antibody absorption test (FTA ABS), which is based on the selective transfer of immunoglobulins through the placenta (Deacon, Falcone, and Harris, 1957; Deacon, Lucas, and Price, 1966).

In practice, the diagnosis of congenital syphilis in babies with obvious clinical stigmatz presents no difficulties, but in the case of the normal neonate with positive results to classical serum tests for syphilis it is impossible on one testing to decide whether these results are due to passive transfer of maternal antibody or to active infection, and for this reason the decision for or against treatment must be delayed (Brambell, 1966; Gärtner, 1965 ; Gitlin, 1965 ; de Murault, Gugler, and Rouler, 1961; de Murault, 1962; Paupe and Meyer, 1969; Quinlivan, 1967; US PHS, 1961; Tesauro, 1965; Wallace, 1965; Wilken, 1965).

With a FTA ABS test performed with conjugated anti 'total globulin' serum, all the syphilitic immunoglobulins are demonstrated without distinguishing between the different varieties IgG, IgM, IgA. Because only IgG passes the placenta, any antitreponemal IgM present in the neonate's serum must have been produced in response to the infant's own organisms, and the detection in the serum of this fraction would justify a diagnosis of congenital syphilis, without waiting for the appearance of osseous, hepatic, and other signs.

Received for publication June 30, 1969

Cette recherche a été entreprise avec l'appui de l'Organisation Mondiale de la Santé
We have tried to determine the presence or absence of this fraction by a test that we have called the immunofluorescent IgM test (IF IgM).

\section{Material}

45 serologically reactive sera were studied. Five were obtained from newly born infants with proven congenital syphilis. Forty came from clearly non-syphilitic newborn children; serum tests for syphilis, initially positive, had become non-reactive zvithout treat- $\stackrel{\square}{\perp}$ ment and we therefore considered these sera as having $\overrightarrow{\vec{B}}$ possessed antibodies passively transferred from mother to infant.

\section{Method}

The technique used was derived from that of the FTA 욱 ABS test (US PHS, 1964), that is the fluorescent treponemal antibody test performed after absorption of sera $O$ with Reiter treponeme ultrasonicate. The individual $₹$ dilutions of sera were made after absorption.

The reaction subtrate was the same Treponema pallidum $D$ as that employed in the FTA test and prepared in our laboratory; a three-step procedure on the siliconed slides 0 o
was used:

(1) Contact for $30 \mathrm{~min}$. at $37^{\circ} \mathrm{C}$. with human serum at $\mathrm{N}$ dilutions of: $1: 5,1: 25,1: 50,1: 100,1: 200$, and N doubling thereafter.

(2) After washing in saline, contact for $30 \mathrm{~min}$. at $37^{\circ} \mathrm{C}$ with rabbit antiserum, specific for human $\operatorname{Ig}{ }^{\star}$, used at $\frac{C}{\Phi}$ a dilution of 1:50.

(3) After washing, contact for $30 \mathrm{~min}$. at $37^{\circ} \mathrm{C}$. with a 0 sheep antirabbit gamma globulin serum conjugated with $\bar{O}$ fluorescein isothiocyanate used at a dilution of $1: 40$.

The titre was taken as the last dilution of the test serum $\stackrel{\square}{\triangle}$ inducing a clear fluorescence of the treponemes.

^Nordic pharmaceuticals and diagnostics-Tilburg Berchem (Antwerp) 


\section{Results}

These are considered in two groups:

(1) Five cases of definite congenital syphilis (Observations 1 to 5) (Table I).

TABLE I Proven congenital syphilis

\begin{tabular}{|c|c|c|c|c|c|}
\hline \multirow{2}{*}{$\begin{array}{l}\text { Observation } \\
\text { No. }\end{array}$} & \multicolumn{3}{|c|}{ Serology } & \multirow{2}{*}{$\begin{array}{l}\text { TPI test } \\
\text { (per cent.) }\end{array}$} & \multirow{2}{*}{ IF IgM } \\
\hline & $B W$ & $K l$ & $V D R L$ & & \\
\hline $\begin{array}{l}1 \\
2 \\
3 \\
4 \\
5\end{array}$ & $++t$ & $\begin{array}{l}+++ \\
++++ \\
+++ \\
+++ \\
N D\end{array}$ & ++ & $\begin{array}{r}N D \\
68 \\
100 \\
88 \\
100\end{array}$ & $\begin{array}{l}+T: \quad 200 \\
+T:=100 \\
+T:=400 \\
+T:=100 \\
+T: \geqslant 3200\end{array}$ \\
\hline
\end{tabular}

$B W \quad=$ Bordet Wassermann

$K l=$ Kline
$V D R L=$ slide test

$N D=$ not done

$$
\} \text { see Wallace (1965) }
$$

(2) Forty clinically normal infants whose mothers had reactive serum tests for syphilis (Observations 6 to 45 ).

In thirty observations (Nos. 6-35), there were classical serological reactions or a positive TPI test, and the IF IgM test was non-reactive at a dilution of $1: 5$.

In seven observations (Nos. 36-42), the serological findings were similar and the IF IgM test was reactive at a dilution of less than $1: 25$.

The last three observations (Nos. 43-45) are shown in Table II.

TABLE II Maternal antibody carry-over

\begin{tabular}{|c|c|c|c|c|c|c|}
\hline \multirow{2}{*}{$\begin{array}{l}\text { Obser- } \\
\text { vation } \\
\text { No. }\end{array}$} & \multicolumn{3}{|l|}{ Serology } & \multicolumn{2}{|c|}{ TPI test (per cent.) } & \multirow{2}{*}{$\begin{array}{l}\text { IF IgM } \\
\text { at birth }\end{array}$} \\
\hline & $B W$ & $K l$ & $V D R L$ & At birth & $\begin{array}{l}6 \\
\text { months } \\
\text { later }\end{array}$ & \\
\hline $\begin{array}{l}43 \\
44 \\
45\end{array}$ & $\begin{array}{l}++++ \\
+++\end{array}$ & $\begin{array}{l}+++ \\
++++ \\
N D\end{array}$ & $\frac{++}{N D}$ & $\begin{array}{l}100 \\
100 \\
100\end{array}$ & $\begin{array}{l}0 \\
4\end{array}$ & $\begin{array}{r}+T: 1600 \\
+T: 100 \\
+T: 200\end{array}$ \\
\hline
\end{tabular}

\section{Discussion}

Antitreponemal antibodies of the IgM type, sometimes at high titres, were demonstrated in the five cases of congenital syphilis. In three subjects the final titre could not be determined because of the small volume of serum at our disposal.

Among the 40 subjects who were obviously not infected, the IF IgM was effectively non-reactive in thirty. We were surprised to find in this group ten subjects in whom the IF IgM test was reactive. The titre was low $(\leqslant 1: 25)$ in seven cases, but in the last three it was higher, reaching $1: 1600$ in Case 43. It is therefore impossible to justify the claim that a reactive IF IgM test gives proof of congenital syphilis. On the other hand, when it is non-reactive, this procedure appears to be of value as an exclusion test for congenital syphilis; the five definitely infected children all presented a positive result.
It is difficult to account for the ten reactive IF $\operatorname{IgM}$ tests in the group of non-syphilitic subjects. In the seven which gave positive results in low titre $(\leqslant 1: 25)$, these may have been false reactions related to the use of a triple-layer staining method. On the other hand, this hypothesis does not seem admissible for the three subjects in which the IF IgM test was reactive at high titres. However, it is conceivable that while the IgM fraction does not pass through the normal placenta, maternal antibody transfer may occur as a result of changes in the placental barrier occurring late in pregnancy.

\section{Summary}

The normal placenta does not allow the passage of the IgM fraction of maternal gamma globulin, and the presence of antitreponemal $\operatorname{IgM}$ in the neonate should be taken as definite evidence of congenital syphilis.

A FTA ABS procedure modified for specific identification of antitreponemal $\operatorname{IgM}$ was employed in the investigation of sera from five proven cases of neonatal congenital syphilis and from forty cases in which reactivity to reagin or treponemal tests was due to transplacental passage of maternal antibody. This immunofluorescent IgM test gave positive results in all five cases of congenital syphilis and negative results in thirty of the forty cases of maternal antibody carry-over. However, in seven of these forty cases the test was positive, but in low titre, possibly for technical reasons, and in three cases results were positive in high titre. It is suggested that, in these three, maternal IgM may have passed the placental barrier because of degenerative changes late in pregnancy. It is concluded that this immunofluorescent IgM test applied to the neonate is not specific for congenital syphilis but may have value as an exclusion test.

\section{References}

Brambell, F. W. R. (1966). Lancet, 2, 1087.

Deacon, W. E., Falcone, V. H., and Harris, A. (1957). Proc. Soc. exp. Biol. (N.Y.), 96, 477.

- Lucas, J. B., and Price, E. V. (1966). F. Amer. med. Ass., 198, 624.

GärTNER, H. (1965). Z. Geburtsh. Gynäk., 164, 225.

GitliN, D. (1965). 'Observations on the selective permeability of the human placenta to plasma proteins and proteins hormones', in 'Radioisotope Techniques in the Study of Protein Metabolism'. Int. Atomic Energy Agency Tech. Rep. Ser., No. 45, p. 197.

Muralt, G. DE (1962). 'La maturation de l'immunité humorale chez l'homme'. Schnabe, Basel and Stuttgart.

- Gugler, E., and Roulet, D. L. A. (1961). Bull. schweiz. Akad. med. Wiss., 17, 245.

Paupe, J., and Meyer, B. (1969). Path. et Biol., 17, 87 and 191. 
Quinlivan, W. L. G. (1967). Amer. F. Physiol., 212, 324. Scotti, A. T., and Logan, L. (1968). F. Pediat., 73, 242.

Tesauro. G. (1965). Bull Soc. roy. belge Gynéc. Obstét., 35, 259.

US PHS (1961). 'Syphilis: Modern Diagnosis and Management', Public Health Service Publication, No. 743, p. 35. United States Government Printing Office, Washington D.C.

(1964). 'Technique for the FTA ABS Test. Supplement to Manual of Serologic Tests for Syphilis'. United States Department of Health, Education and Welfare, Washington, D.C.

Wallace, A. L. (1965). Amer. F. clin. Path., 44, 712.

WILKEN, H. (1955). Münch. med. Wschr., 107, 2343.

\section{L'épreuve de la recherche de l'anticorps} spécifique IgM dans la syphilis congénitale du nouveau-né

SOMMAIRE

Le placenta normal ne permet pas le passage de la fraction IgM des gamma-globulines maternelles et la présence
d'IgM antitréponémique chez le nouveau-né devrait $\bar{O}$ fournir la preuve certaine de l'existence d'une syphilis 흐 congénitale.

Une technique modifiée du FTA-ABS a été utilisée $\overparen{\widetilde{\phi}}$ pour identifier l'IgM antitréponémique dans cinq sérums provenant de cas certains de syphilis congénitale du $s$ nouveau-né et pour quarante cas pour lesquels la réponse $\overrightarrow{0}$ aux tests de réagine et aux tests tréponémiques était due au passage transplacentaire des anticorps maternels. Cette $\vec{\omega}$ recherche de l'IgM par immunofluorescence fut positive $O$ dans les cinq cas de syphilis congénitale et négative dans trente des quarante cas de transmission des anticorps + maternels. Cependant, dans sept de ces quarante cas, $\stackrel{-}{-}$ l'épreuve fut positive, mais à un titre faible, probablement pour des raisons techniques, et dans trois cas, les résultats $\infty$ furent positifs à un titre élevé. On pense que, pour ces $\frac{\circ}{3}$ trois cas, l'IgM maternelle a pu traverser la barrière placentaire du fait de modifications dégénératives sur- Tr venues tardivement au cours de la grossesse. On conclue $\bar{O}$ que cette épreuve de recherche de l'IgM par l'immunofluorescence chez le nouveau-né n'est pas spécifique de la syphilis congénitale mais qu'elle peut avoir une valeur en tant qu'épreuve d'élimination. 